\section{Impact of Knowledge and Positive Attitudes About Avian Influenza (H5N1 Virus Infection) on Infection Control and Influenza Vaccination Practices of Thai Healthcare Workers}

To the Editor-Few data are available concerning healthcare workers' (HCWs') knowledge and attitudes regarding avian influenza (H5N1 virus infection) and what effect their knowledge and attitudes have on infection control practices for suspected or documented cases of infections spread by droplet or airborne transmission and on influenza vaccination practices in an area where $\mathrm{H} 5 \mathrm{~N} 1$ is endemic. We designed a crosssectional survey that collected data on these factors to guide the development of public health policy for prevention of the transmission of influenza in healthcare settings during a pandemic.

The study was performed at Thammasat University Hospital, a 500-bed academic hospital, and Pratumthani Hospital, an acute care 300-bed government hospital, which are the only tertiary care centers in Pratumthani, Thailand. We surveyed HCWs in the departments of medicine, pediatrics, emergency medicine, family practice, and intensive care, because these HCWs are at highest risk for nosocomial influenza. In 2004, the Thai government started offering free influenza vaccination to HCWs at Pratumthani Hospital, but not at Thammasat University Hospital. During July and December 2006, we surveyed nurses, attending physicians, and resident physicians. We collected data on each HCW's demographic characteristics, occupation, and previous experience caring for patients who had or were suspected to have $\mathrm{H} 5 \mathrm{~N} 1$ infection; the HCW's knowledge about $\mathrm{H} 5 \mathrm{~N} 1$ infection and modes of transmission; and the HCW's attitudes toward $\mathrm{H} 5 \mathrm{~N} 1$ infection, infection control practices for dealing with patients with suspected or proven cases of infections spread by droplet or airborne transmission, and influenza vaccination practices. Definitions of $\mathrm{H} 5 \mathrm{~N} 1$ infection and disease transmission were derived from World Health Organization criteria. ${ }^{1}$ The survey was pilot-tested then modified to assure clarity and coherence.

Three hundred twenty-two HCWs participated in the survey $(215$ [86\%] of $250 \mathrm{HCWs}$ at Thammasat University Hospital and 107 [86\%] of 124 HCWs at Pratumthani Hospital). The demographic characteristics of participants are given in the Table. Of the 322 participating HCWs, 316 (98\%) correctly defined $\mathrm{H} 5 \mathrm{~N} 1$ infection as a contagious infection caused by a virus that can affect all species of birds, and 282 $(88 \%)$ knew that $\mathrm{H} 5 \mathrm{~N} 1$ virus can be transmitted by touching infected eggs or poultry and can be transmitted from patients to HCWs. All HCWs identified poultry and wild birds as common vectors, and $275(85 \%)$ answered all questions correctly. Two hundred ninety-nine HCWs (93\%) believed there would be an outbreak of $\mathrm{H} 5 \mathrm{Nl}$ infection among humans in Thailand in the future, and 289 (90\%) accepted the personal risk of caring for H5N1-infected patients. Although 139 HCWs $(43 \%)$ believed that they had little control over their chance of contracting $\mathrm{H} 5 \mathrm{~N} 1$ infection and $120(37 \%)$ were afraid of falling ill, 306 (95\%) would not consider a job change even if they were required to care for infected patients. With regard to infection control practices for caring for patients with suspected or documented cases of infections spread by droplet or airborne transmission, $113 \mathrm{HCWs} \mathrm{(35 \% )}$ reported washing their hands before patient contact, 236 (73\%) reported washing their hands after patient contact, and $153(48 \%)$ practiced cough etiquette. The proportion of HCWs who used personal protective equipment varied from $24 \%$ to $65 \%$, depending on the item. Only 106 HCWs (33\%) wore all recommended personal protective equipment and practiced cough etiquette when evaluating patients with a suspected or documented case of infections spread by droplet or airborne transmission. There was no difference in knowledge, attitudes, or infection control practices by HCW specialty.

One hundred fifty HCWs (47\%) reported receiving influenza vaccination in the previous year (91 [85\%] of 107 at Pratumthani Hospital and 59 [27\%] of 215 at Thammasat University Hospital; $P<.001$ ). The main reasons that HCWs gave for receiving vaccination were self-protection (reported by $126 \mathrm{HCWs}[84 \%]$ ); protection of patients (84 [56\%]); the desire to avoid missing work (38 [25\%]); the belief that it was better to be vaccinated than to contract influenza ( 32 [21\%]); and the recommendation of their peers (23 [15\%]). By multivariate analysis, 2 factors were associated with an HCW's reporting having been vaccinated: location at Pratumthani Hospital rather than Thammasat University Hospital (adjusted odds ratio [aOR], 1.5 [95\% confidence interval $\{\mathrm{CI}\}, 1.05-65.9])$ and prior experience caring for patients who had or were suspected of having $\mathrm{H} 5 \mathrm{~N} 1$ infection (aOR, 2.6 [95\% CI, 1.2-71.1]). Among the 172 HCWs who reported not being vaccinated, the main reasons given were the unavailability of free vaccine (reported by 136 [79\%]); fear of side effects $(82[48 \%])$; and the belief that influenza is not a severe disease (64 [37\%]). The main reason for nonvaccination among HCWs at Thammasat University Hospital was unavailability of free vaccine (reported by 136 [87\%] at Thammasat University Hospital and $0[0 \%]$ at Pratumthani Hospital; $P<.001$ ). The reasons among HCWs at Pratumthani Hospital were more diverse (fear of side effects was reported by 16 HCWs [15\%], the belief that influenza is not a severe disease by $16[15 \%]$, and the belief that vaccination is not effective by $16[15 \%])$. Attitudes related to vaccination did not differ by specialty.

The majority of HCWs surveyed in this area of $\mathrm{H} 5 \mathrm{~N} 1$ virus endemicity were knowledgeable about $\mathrm{H} 5 \mathrm{~N} 1$ infection. How- 
TABLE. Findings of the Survey of Healthcare Workers (HCWs) at 2 Hospitals in Thailand Regarding Avian Influenza (H5Nl Virus Infection)

\begin{tabular}{|c|c|c|c|}
\hline Variable & $\begin{array}{c}\text { Thammasat } \\
\text { University } \\
\text { Hospital }\end{array}$ & $\begin{array}{c}\text { Pratumthani } \\
\text { Hospital }\end{array}$ & $P^{a}$ \\
\hline No. of HCW respondents & 215 & 107 & \\
\hline Age in years, median (range) & $32(24-51)$ & $32(21-58)$ & .71 \\
\hline Female sex & $131(61)$ & $62(58)$ & .82 \\
\hline Occupation & & & $<.001$ \\
\hline Resident physician & $37(17)$ & $8(7)$ & \\
\hline Attending physician & $88(41)$ & $17(16)$ & \\
\hline Nurse & $90(42)$ & $82(76)$ & \\
\hline No. of years in practice & & & .94 \\
\hline$<5$ years & $72(33)$ & $40(37)$ & \\
\hline $5-10$ years & $82(38)$ & $33(31)$ & \\
\hline$>10$ years & $61(29)$ & $34(32)$ & \\
\hline \multicolumn{4}{|l|}{ Knowledge about $\mathrm{H} 5 \mathrm{~N} 1$ infection $^{\mathrm{b}}$} \\
\hline Definition & $213(99)$ & $103(96)$ & .95 \\
\hline Poultry and wild birds are common vector & $215(100)$ & $107(100)$ & .99 \\
\hline Transmission by eating uncooked infected poultry & $185(86)$ & $97(91)$ & .76 \\
\hline Transmission by eating uncooked infected eggs & $203(94)$ & $103(96)$ & .85 \\
\hline Transmission by touching infected poultry & $209(97)$ & $103(96)$ & .92 \\
\hline Transmission by touching infected eggs & $194(90)$ & $100(93)$ & .91 \\
\hline Human-to-human transmission has been reported & $192(89)$ & $90(84)$ & .78 \\
\hline \multicolumn{4}{|l|}{ Attitudes toward $\mathrm{H} 5 \mathrm{~N} 1$ infection } \\
\hline $\begin{array}{l}\text { I believe that } \mathrm{H} 5 \mathrm{~N} 1 \text { infection is likely to reoccur } \\
\text { in Thailand }\end{array}$ & $210(98)$ & $89(83)$ & .71 \\
\hline I accept the risk of $\mathrm{H} 5 \mathrm{~N} 1$ infection as part of my job & $201(93)$ & $88(82)$ & .76 \\
\hline I should not care for H5N1-infected patients & $13(6)$ & $4(4)$ & .89 \\
\hline I have no control over if I will be infected with $\mathrm{H} 5 \mathrm{~N} 1$ & $89(41)$ & $50(47)$ & .85 \\
\hline I am afraid of falling ill with $\mathrm{H} 5 \mathrm{~N} 1$ infection & $80(37)$ & $40(37)$ & .99 \\
\hline $\begin{array}{l}\text { I will consider resigning because of the risk of } \\
\mathrm{H} 5 \mathrm{~N} 1 \text { infection }\end{array}$ & $12(6)$ & $4(4)$ & .46 \\
\hline
\end{tabular}

ever, there was a gap between their knowledge and their actual infection control and influenza vaccination practices. Although direct exposure to infected poultry is the main route of $\mathrm{H} 5 \mathrm{~N} 1$ virus transmission to humans, human-to-human transmission has been increasingly reported. ${ }^{2-4}$ Low rates of adherence to World Health Organization recommendations on how to avoid the spread of $\mathrm{H} 5 \mathrm{~N} 1$ virus in healthcare settings and through food preparation have also been reported. ${ }^{5,6}$ Similar to a previous study, ${ }^{7}$ more than half of our HCWs held a positive attitude in response to the impending outbreak of H5N1 infection. In addition, HCWs' increased acceptance of influenza vaccination was associated with the threat of an impending avian influenza epidemic. ${ }^{8-10}$

Our study was limited by the relatively small sample size and by possible recall bias. The fact that our survey did not undergo psychometric validity testing and its lack of gradations in response types may have led to oversimplified survey results. Despite these limitations, our study suggests the need to monitor infection control practices to help minimize influenza transmission in hospitals in areas where $\mathrm{H} 5 \mathrm{~N} 1$ virus is endemic. Improvement of influenza vaccination administration may be promoted by education and by providing free vaccinations for HCWs at high risk of infection. Additional studies to evaluate knowledge, attitudes, and infection control practices among HCWs in areas where $\mathrm{H} 5 \mathrm{~N} 1$ infection is endemic are needed.

\section{ACKNOWLEDGMENTS}

Financial support. This work was supported by a grant from the Thai Research Fund and the National Center of Genetic Engineering and Biotechnology, National Science and Technology Development Agency (BT-B-01MG-13-5019) (to A.A.). D.K.W. is supported by a National Institutes of Health (NIH)/ National Institute for Allergy and Infectious Diseases (NIAID) Career Development Award (5K23AI050585-05). V.J.F. is supported by the Centers for Disease Control Epicenters Program (1U1C1000033301), the National Institutes of Health (K12HDO52194), and an NIH Career Development Award (K24A1A106779401). 
Potential conflicts of interest. D.K.W. is a consultant for Enturia and $3 \mathrm{M}$ Healthcare. V.J.F. is a consultant for Merck and has served on the speakers' bureau for Merck and Pfizer. All other authors report no conflicts of interest relevant to this study.

Anucha Apisarnthanarak, MD; Piphob Phattanakeitchai, MD; David K. Warren, MD; Victoria J. Fraser, MD

From the Division of Infectious Diseases, Thammasat University Hospital, Pratumthani, Thailand (A.A., P.P.); and the Division of Infectious Diseases, Washington University School of Medicine, Saint Louis, Missouri (D.K.W., V.J.F.).

Address reprint requests to Anucha Apisarnthanarak, MD, Division of Infectious Diseases, Faculty of Medicine, Thammasat University Hospital, Pratumthani, Thailand, 12120 (anapisarn@yahoo.com).

Infect Control Hosp Epidemiol 2008; 29:472-474

(C) 2008 by The Society for Healthcare Epidemiology of America. All rights reserved. 0899-823X/2008/2905-0021\$15.00. DOI: $10.1086 / 587495$

\section{REFERENCES}

1. Writing Committee of the World Health Organization (WHO) Consultation on Human Influenza A/H5 Avian Influenza A (H5N1) infection in humans. $N$ Engl J Med 2005; 353:1374-1385.

2. Buxton Bridges C, Katz JM, Seto WH, et al. Risk of influenza A (H5N1) infection among health care workers exposed to patients with influenza A (H5N1), Hong Kong. J Infect Dis 2000; 181:344-348.

3. Ungchusak K, Auewarakul P, Dowell SF, et al. Probable person-to-person transmission of avian influenza A (H5N1). $N$ Engl J Med 2005; 352: 333-340.

4. Kandun IN, Wibisono H, Sedyaningsih ER, et al. Three Indonesian clusters of $\mathrm{H} 5 \mathrm{~N} 1$ virus infection in 2005. N Engl J Med 2006; 355:2186-2194.

5. Apisarnthanarak $A$, Warren DK, Fraser VJ. Issues relevant to the adoption and modification of hospital infection-control recommendations for avian influenza (H5N1 infection) in developing countries. Clin Infect Dis 2007; 45:1338-1342.

6. World Health Organization. Public health interventions for prevention and control of avian influenza. A manual for improving biosecurity in the food supply chain: focusing on live animal markets. New Delhi, India: Regional Office for South-East Asia; 2006.

7. Tam DKP, Lee S, Lee SS. Impact of SARS on avian influenza preparedness in healthcare workers. Infection 2007; 35:320-325.

8. Yang KS, Fong YT, Koh D, Lim MK. High coverage of influenza vaccination among healthcare workers can be achieved during heightened awareness of impending threat. Ann Acad Med (Singapore) 2007; 36: 384-387.

9. Maltezou HC, Maragos A, Halharapi T, et al. Factors influencing influenza vaccination rates among healthcare workers in Greek hospitals. I Hosp Infect 2007; 66:156-159.

10. Tam DKP, Lee SS, Lee S. Impact of severe acute respiratory syndrome and the perceived avian influenza epidemic on the increased rate of influenza vaccination among nurses in Hong Kong. Infect Control Hosp Epidemiol 2008; 29:256-261.

\section{Disinfectants Containing Chlorine: An Occupational Hazard?}

The Belgian national guidelines to prevent transmission of Clostridium difficile in hospitals state that it is justified to use a disinfectant containing 1,000 or $5,000 \mathrm{ppm}$ free chlorine to disinfect the rooms of patients with $C$. difficile-associated disease (CDAD). ${ }^{1}$ Concern has risen about the occupational safety of the cleaning employees using the disinfectant at this concentration. We conducted a small test to evaluate the concentration of chlorine in the air while the cleaning employees disinfected a patient's room according to our standard procedure (furniture, door, bathroom, and floor).

The chlorine-containing disinfectant in our hospital is made from 3 tablets of sodium dichloroisocyanurate dihydrate dissolved in $1 \mathrm{~L}$ of water to obtain a concentration of 4,500 ppm free chlorine. During the test, the door and windows were closed. Air samples were taken in the neighborhood of the cleaning employees (distance, approximately 1 $\mathrm{m})$ during the decontamination procedure. The samples were analyzed according to method P\&CAM 209 in the NIOSH Manual of Analytical Methods. ${ }^{2}$

During an 18-minute decontamination with a solution containing 4,500 ppm free chlorine, we sampled $18.3 \mathrm{~L}$ of air and found traces of chlorine that were not quantifiable. During a 15-minute decontamination with a solution containing $1,500 \mathrm{ppm}$ free chlorine, we sampled $15.2 \mathrm{~L}$ of air and could not detect chlorine at all. On the basis of these results, we concluded that there is no occupational hazard for the cleaning employees while performing a decontamination procedure with a solution containing $4,500 \mathrm{ppm}$ free chlorine made from sodium dichloroisocyanurate dihydrate tablets.

\section{ACKNOWLEDGMENTS}

Potential conflicts of interest. All authors report no conflicts of interest relevant to this study.

\section{Frank Andreas Van Laer, RN, CIC; Rudi Verdyck, EM;} Hilde Jansens, MD; Elke Coenen, MD

From the Departments of Infection Control (F.A.V.L., H.J.) and Occupational Health (R.V., E.C.), University Hospital Antwerp, Antwerp, Belgium.

Address reprint requests to Frank Andreas Van Laer, Infection Control, University Hospital Antwerp, Wilrijkstraat 10, Edegem, Antwerpen 2650, Belgium (Frank.Van.Laer@uza.be).

Infect Control Hosp Epidemiol 2008; 29:474-474

(C) 2008 by The Society for Healthcare Epidemiology of America. All rights reserved. 0899-823X/2008/2905-0022\$15.00. DOI: 10.1086/533481

\section{REF E R E N C ES}

1. Simon A. Belgische aanbevelingen voor de preventie van infecties met Clostridium difficile. Noso-info 2006; 10:6-7.

2. National Institute for Occupational Safety and Health (NIOSH) Manual of Analytical Methods. 4th ed. Cincinnati, OH: US Department of Health and Human Services, 1994. 